\title{
Investigation of Near-Transducer Errors in Acoustic Doppler Current Profiler Measurements Using Experimental and Numerical Method
}

\author{
Dongsu Kim ${ }^{1}$ and Boosik Kang ${ }^{1^{*}}$ \\ ${ }^{1}$ Department of Civil \& Environmental Engineering, Dankook University
}

$\mathrm{ADCP}$ 계기 부근에서 발생하는 관측 오차의 실험 및 수치모의에
의한 고찰

김동수 ${ }^{1}$, 강부식 $^{1^{*}}$

${ }^{1}$ 단국대학교 토목환경공학과

\begin{abstract}
This paper reports results of a joint experimental and numerical investigation of the causes of near-transducer errors due to the combined effect of acoustic and ADCP-induced flow disturbance near the ADCP transducer. The laboratory study focused on an isolated ADCP (deployment without boat). Measurements of the flow disturbance produced by the ADCP in vertical and horizontal planes were obtained acquiring measurements with an Acoustic Doppler Velocimeter (ADV). Concurrent measurements with ADCP and ADV were made to infer additional near-transducer effects in the ADCP measurements. The numerical investigation was designed to extend the inquiry on the near-transducer potential errors when the ADCP is deployed from a boat. Large Eddy Simulation (LES) was conducted to obtain the extent and magnitude of the disturbances induced by the drag acting on a boat-mounted ADCP and by the blockage effect of the instrument and boat. It is found the velocities measured by the ADCP are biased low and differ substantially from the undisturbed channel flow solution within a limited layer beneath the instrument.
\end{abstract}

요 약 본 논문은 $\mathrm{ADCP}$ 계측기기 부근에서 음향학적인 그리고 $\mathrm{ADCP}$ 계기로 인해 발생하는 흐름의 교란에 기인한 속도 오차에 대한 원인들을 실험 및 수치모의를 통해 고찰한다. 실험실에서의 연구는 선박에 탑재되지 않은 독립된 $\mathrm{ADCP}$ 에 대해 수행하였고, 수평 및 수직면에서 $\mathrm{ADCP}$ 에 의해 유발되는 흐름 교란은 $\mathrm{ADV}$ 를 이용하여 관측하였다. 그리고 $\mathrm{ADCP}$ 와 $\mathrm{ADV}$ 의 동시적 측정이 $\mathrm{ADCP}$ 계측에 있어 추가적인 계측기기 부근의 영향들을 고려하기 위해 수행되 었다. 수치모의는 $\mathrm{ADCP}$ 가 선박에 탑재되었을 때 $\mathrm{ADCP}$ 계기 부근에 발생하는 잠재적인 오차에 대해 연구하기 위해 설계되었다. 수치해석 기법 사용된 LES (Large Eddy Simulation)는 선박에 탑재된 ADCP에 작용하는 항력과 계기와 선박의 막음효과에 의해 발생하는 흐름의 교란의 크기와 범위를 모의하였다. 결과로 $\mathrm{ADCP}$ 에 의해 관측된 속도는 계 측기기 하단의 제한된 범위 내에서 일정 정도 오차를 보였고 교란되지 않은 하천의 흐름 조건에 따라 오차가 실질적 으로 다르게 나타났다.

Key Words : ADCP, Near-Transducer Errors, LES, ADV

\section{Introduction}

Technological advances in acoustics have resulted in a new type of four-transducer acoustic Doppler current profiler (ADCP) with a much shorter damping time than older ADCPs. This new type of ADCP, which is a

This research was supported by the Graduate Research Assistantship of Dankook University.

"Corresponding Author : Kang, Boosik (bskang@dankook.ac.kr)

Received December 13, 2010

Revised February 7, 2011

Accepted February 10, 2011 
Teledyne/RDI $1200-\mathrm{kHz}$ ZedHed instrument, is able to measure the flow velocities closer to the transducers $(\sim 5$ $\mathrm{cm}$ ) than older models (Mueller et al., 2007). The ZedHed appeals to users interested in measuring shallow flows $(\sim 50 \mathrm{~cm})$ and water velocities close to the free surface which is of great interest to many applications in river engineering and in experiments conducted in laboratory flumes. The drag acting on the ADCP and the ADCP blockage to the flow disturb the flow field being measured. If the ADCP is mounted on a boat, a common case when ADCP is used in the field, than the presence of the boat further modifies the flow field around the instrument.

Recent field, laboratory, and computational fluid dynamics (CFD) studies show that ADCPs can significantly disturb the measured flow field. Gartner and Ganju (2002) compared streamwise velocities measured in field conditions by a ZedHed with concurrent measurements by a high frequency, bi-static, acoustic Doppler point-velocity meter (ADV). They measured in the Delta Mendota Canal at Byron, California, with the profiler fixed to a bridge while the flow was 5-m deep and the mean velocity was about $1 \mathrm{~m} / \mathrm{s}$. Their field comparisons show that the ZedHed disturbs the flow field up to $50 \mathrm{~cm}$ away from the ADCP transducers, and that the streamwise velocities measured by the ADCP were up to $15 \%$ lower than those measured by the ADV. Gartner and Ganju (2002) attributed this to the flow disturbance near the ADCP transducer, with the signal decorrelation from high current speed being a second probable cause. Abad et al. (2004) and Muste et al. (2006) evaluated the flow disturbance induced by acoustic profilers in laboratory flumes. Abad et al. (2004) compared undisturbed flow with the flow disturbed by a three-beam acoustic Doppler profiler (ADP) manufactured by Sontek/YSI using particle image velocimetry.

This study uses a coupled, complementary approach for investigating the near transducer errors bringing in new experimental evidence and evaluating new measurement scenarios that were not covered by previous studies. The study uses the same probe type in the numerical and experimental studies to facilitate interpretation of the findings. While the problems reported in this study are relevant for all the ADCPs, disregard of their manufacturer, the study uses for exemplifications the configuration, geometry and processing algorithms associated with the Teledyne/RDI 1200-kHz ZedHed ADCP. The experimental study reports spatial maps of the disturbance created by the presence of an isolated (no boat) ADCP probe in the vertical and horizontal planes centered on the instrument axis. It also compares concurrent ADCP and ADV (considered reference instrument) measurements taken in the axis to illustrate the difference between the reported and actual velocity distribution in the instrument axis. The numerical investigation uses advanced eddy resolving simulations (Large Eddy Simulation -LES) to assess the boat-mounted ADCP capability to quantify the mean and turbulence characteristics compared to the actual (undisturbed) channel flow characteristics (see Tokyay et al, 2008 for more details). LES simulations of channel flows in wide domains are free of secondary currents induced by the finite width of the flume (this is a significant problem with laboratory investigations of ADCP-induced flow disturbances) and the incoming flow can be set to correspond to fully-developed turbulent channel flow. Similar to the experimental approach that used ADV measurements to estimate errors due to lack of homogeneity in the horizontal layers, the along-beam velocities from LES were transformed with the ADCP algorithm to estimate the velocities in orthogonal coordinates that would be obtained in ADCP measurements at locations under the ADCP. By using identical ADCP probe for the experimental and numerical simulations, the coupled study allows to distinguish the effect of the flow disturbance (pure hydrodynamic effects) from that of the other effects involved in the ADCP measurements (e.g., acoustic, processing algorithms, mechanic).

\section{Experimental Arrangement and Procedure}

The design of the experiment took into consideration the limitations encountered in previous laboratory studies. A large-scale facility was used for the experiments and customized tests were conducted to investigate the quality of the flume flow, instrument-flume and instrument -instrument interactions. The tests were conducted in the 
IIHR's Environmental Flow Facility. This facility consists of a non-tilting, re-circulating, $20 \mathrm{~m}$-long, $3 \mathrm{~m}$-wide, and 2.3 m-deep flume. The ADCP measurements were conducted with an RDI 1200-kHz ZedHed (rdinstruments. com). A high-resolution Sontek /YSI Micro-ADV (sontek.com) was used for the ADV measurements. The ADV accuracy was traced to primary standards through calibration against a Laser Doppler Velocimeter. The measurements reported here were conducted using several experimental setups. Figure 1 illustrates the layouts of the ADCP and ADV arrangements.

\section{Numerical Simulations}

The LES code used in this study is a massively parallel solver that uses a collocated finite-volume scheme to solve the filtered Navier-Stokes equations with the dynamic Smagorinsky model (Mahesh et al., 2004). The fractional-step algorithm is second-order accurate in both space and time. All the operators in the governing equations, including the convective terms, are discretized using central schemes.

The computational domain used for the simulation of the flow past a four-transducer, boat-mounted-ADCP (Figure 2a) placed near the free surface is shown in Figure $2 b$. The boat is aligned with the streamwise direction and the ADCP is positioned at a small distance upstream of the boat's bow. The channel depth, D, is used as the length scale in LES. The ADCP, the diameter of which is $=0.06 \mathrm{D}$, is submerged $\mathrm{h}=0.02 \mathrm{D}$ into the flow. The boat length and width are $1.2 \mathrm{D}$ and $0.4 \mathrm{D}$, respectively, and the boat's draft (submergence depth) is $h_{1}=0.075 D$. The velocity scale is the channel bulk velocity, $U_{0}$. The incoming channel flow in LES was fully developed and contained resolved turbulence fluctuations at the Reynolds number of the simulation $\left(R e \sim 10^{4}\right.$ ). The free surface was simulated as a rigid lid (the Froude number was much smaller than one). The unstructured mesh comprises approximately 2 million hexahedral elements and the viscous sub-layers are resolved in the simulation.

\section{Complementary findings from the simulation and experimental study}

The extent of the flow disturbance created by the submersed part of the probe, the effect of the immersion of the velocity field in the vicinity of the probe were studied experimentally for a set of flow characteristics. The Reynolds number in LES was about one order of magnitude lower compared to the experiments, so scale effects besides the additional presence of the boat in LES study may play a role when comparing LES and experimental results. In the case of an isolated ADCP, the submerged part of the ADCP near the free surface creates a stagnation flow region upstream of the profiler. The flow beneath the ADCP is accelerated as it passes beneath the profiler and a downflow is created in front of the ADCP. The flow then slows down within the portion of the wake downstream of the ADCP but within the profilers draft as it ascends toward the free surface. It then seems to tend to the undisturbed velocity profile towards the downstream side of the profiler (Muste et al., 2006). As a result, the maximum streamwise velocity occurs under the ADCP (see Figure 3a), while the maximum downward and upward vertical velocities occur at the front and back ends of the profiler, respectively (see Figure 3c). Noticeably, for this flow condition, is that the locations of the maximum vertical velocity disturbance (e.g., see Figure 3c) coincide with the acoustic paths of Beams 3 and 4.

In the case of a boat-mounted ADCP, the overall flow pattern is more complicated compared to the case of an isolated ADCP, particularly when the ADCP is located inside the decelerating flow region induced by the boat (conditions in LES study). The boat plays the same role as the ADCP in terms of the flow blockage. This blockage induces strong adverse pressure gradients in the streamwise direction and a downflow as the flow tries to adjust to the presence of the boat and then pass it (see Figure 3d). Two phenomena disturb the flow field around the ADCP location. Because of the blockage induced by the submerged part of the ADCP, the streamwise velocities beneath the ADCP and immediately downstream of it tend to increase compared to the velocities when the flow is undisturbed. On the other hand, the presence of the boat some distance downstream 
of the ADCP decelerates the flow and decreases the overall velocity magnitude in the region in the vicinity of the ADCP.

The combined disturbance (due to the boat and the ADCP) of the streamwise velocity field in the vicinity of the ADCP can be relatively small compared to the one expected around an isolated ADCP. This can be observed by comparing the streamwise velocity fields in Figs. 3a and $3 \mathrm{~b}$. In the experiments, the maximum amplification of the streamwise velocity beneath the ADCP was around $30 \%$ while in LES the maximum amplification is only about $10 \%$ and the disturbance field beneath the ADCP decays faster with the distance from the instrument. In LES, beneath the ADCP, at distances larger than $0.3 \Omega$ from the transducers, the magnitude of the velocity disturbance is quite small (less than $3 \%$ of the undisturbed value) due to the competing effects of the flow accelerating as it passes below the ADCP and the flow decelerating as it approaches the much larger blockage induced by the boat.

Comparison of Figs. $3 \mathrm{c}$ and $3 \mathrm{~d}$ shows the extent and magnitude of the disturbance field for the vertical velocity in the symmetry plane cutting through the center of the ADCP are comparable to those for isolated ADCPs. For instance, in LES the maximum relative error within $0.6 \Omega$ from the ADCP is about $10 \%$ the mean velocity in the channel. Beneath the ADCP, the bias in the vertical velocity due to the ADCP and boat disturbance decreases monotonically with depth to less than $2 \%$ at $9 \Omega$ below the free surface. The presence of the boat at a relatively small distance from the ADCP forces the vertical velocity to be negative in most of the region between the ADCP and the start of the relatively flat part of the boat bottom. Still the magnitude of the vertical velocity in this region is smaller than the one recorded around the upstream side of the ADCP. In both experiment and LES, the velocity disturbance in the symmetry plane upstream and beneath the ADCP does not exceed $3 \Omega$. Both investigations illustrate that the flow near the ADCP is three dimensional. The shape of the flow field near the ADCP clearly violates the assumption of flow homogeneity in horizontal layers, on which the ADCP algorithm relies to estimate velocities in Cartesian coordinates from along-beam (radial) velocity data.

The flow visualization displayed in Figure 3 leads to the conclusion that Beam 3 pointing upstream, as well as Beams 1 and 2 that point in the transverse direction are not strongly influenced by the presence of the boat carrying the ADCP, hence a comparison of their experimental and numerical simulation results might be considered. In the case of the boat mounted ADCP, Beam 4 records information at locations situated beneath the boat where the flow is accelerated due to the boat submergence. Thus, a direct comparison is not possible for Beam 4. The comparisons of the along-beam velocities and of the Cartesian velocities beneath the instrument obtained using the ADCP algorithm are important as the experimental investigation approach captures the effects related to mechanical (e.g., ringing), acoustics (e.g., Doppler effect), and processing (e.g., algorithm, signal decorrelation) aspects of ADCP operations that are not simulated in the numerical experiments.

The differences between the two investigative approaches can potentially shed light on the causes of low bias in the near-transducer errors in addition to the effect of flow disturbance that is captured by both approaches. Figure 4 compares the along-beam velocities measured by the ADCP and the ADV and estimated from time series of the instantaneous Cartesian velocity components obtained from LES at locations along the paths of the acoustic beams of the ADCP. The along-beam velocities for Beam 3 denoted $V_{3}$ are close to $0.35 U_{o}$ ( $U_{o}$ is the mean velocity in the channel). The along-beam velocities measured by the ADCP are in good agreement with the ones measured by the ADV for same flow (no boat) and even with the ones obtained from LES (boat was present). Some disagreement is observed near the instrument $(\mathrm{y} / \mathrm{H}>0.7)$. The agreement is even better for the along-beam velocities measured along Beam $2\left(V_{2}\right)$. The slightly larger magnitude of $V_{2}$ close to the free surface obtained from LES is due to the adverse pressure gradients induced by the submerged part of the boat which is quite wide. These pressure gradients induce velocity disturbances over a larger region in the lateral direction compared to the case when only the ADCP is present.

The "along-beam" velocity estimates from LES and ADCP can be combined according to the algorithm used 
by four-transducer ADCPs to estimate the streamwise, vertical and spanwise velocity components, which are then taken as estimates along the vertical line beneath the ADCP. Observe the streamwise velocities measured by ADV are very close to the undisturbed LES solution validating the accuracy of the numerical simulation results. The ADCP predictions are biased low in the upper part of the channel. Same is true for the streamwise velocity predicted using the ADCP algorithm based on time series collected from LES. Still the difference with the undisturbed LES solution is slightly smaller for the LES results. The effect of the Reynolds number is not significant.

\section{Conclusions}

The present experiments and LES simulations provide a quantitative estimation of the magnitude and shape of the disturbance to the flow field (with respect to the undisturbed channel flow) around an isolated ADCP and a boat-mounted ADCP for the mean velocity components. The disturbance to the flow field around the boat-mounted ADCP was found to be somewhat different from the one quantified around isolated ADCP's. When only the ADCP is present, the vertical velocity becomes negative (oriented away from the free surface) in front of the ADCP and then positive (toward the free surface) past the ADCP. LES shows that this is not what happens in the disturbed flow field around a boat-mounted-ADCP when the ADCP is placed at a relatively small distance from the upstream edge of the boat. The differences between these two cases are due to the deceleration of the flow as it approaches the boat. The blockage effect induced by the boat is much larger than the one due to the ADCP. The combined presence of the boat and the ADCP induces a relatively smaller disturbance of the streamwise velocity in the vicinity of the ADCP with respect to the disturbance field observed around an isolated ADCP. The differences are much smaller for the vertical velocity disturbance field.

The comparison of the along-beam velocities between $\mathrm{ADCP}$ and ADV allowed quantifying some of the errors that are affecting ADCP measurements (e.g., ringing, signal decorrelation, capturing and processing the signal by the ADCP, the fact that ADCP predicts a zero velocity when velocity vector is perpendicular to the beam direction). More details on the proportion of individual error contributions to the total error require further study.

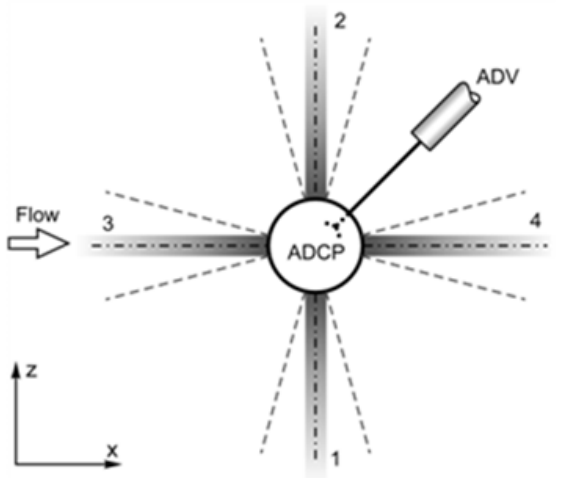

[Fig. 1] ADCP and ADV experimental setup: a) on-axis measurements (view from the top); b) in-beam measurements (view from the top)
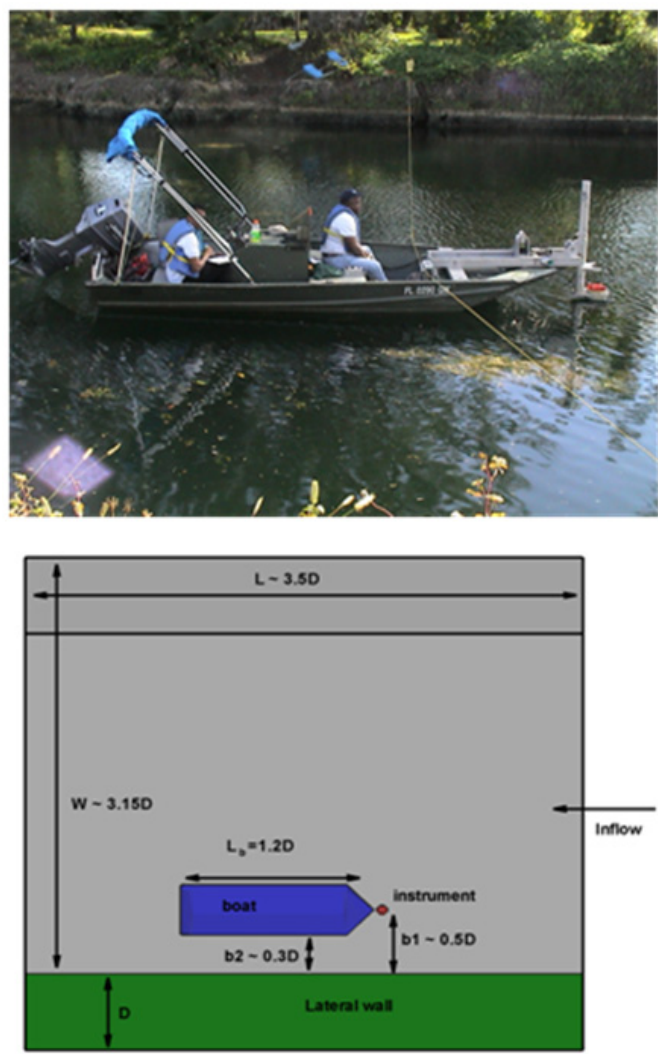

[Fig. 2] View of ADCP installed on a boat (a) and computational domain (b). 

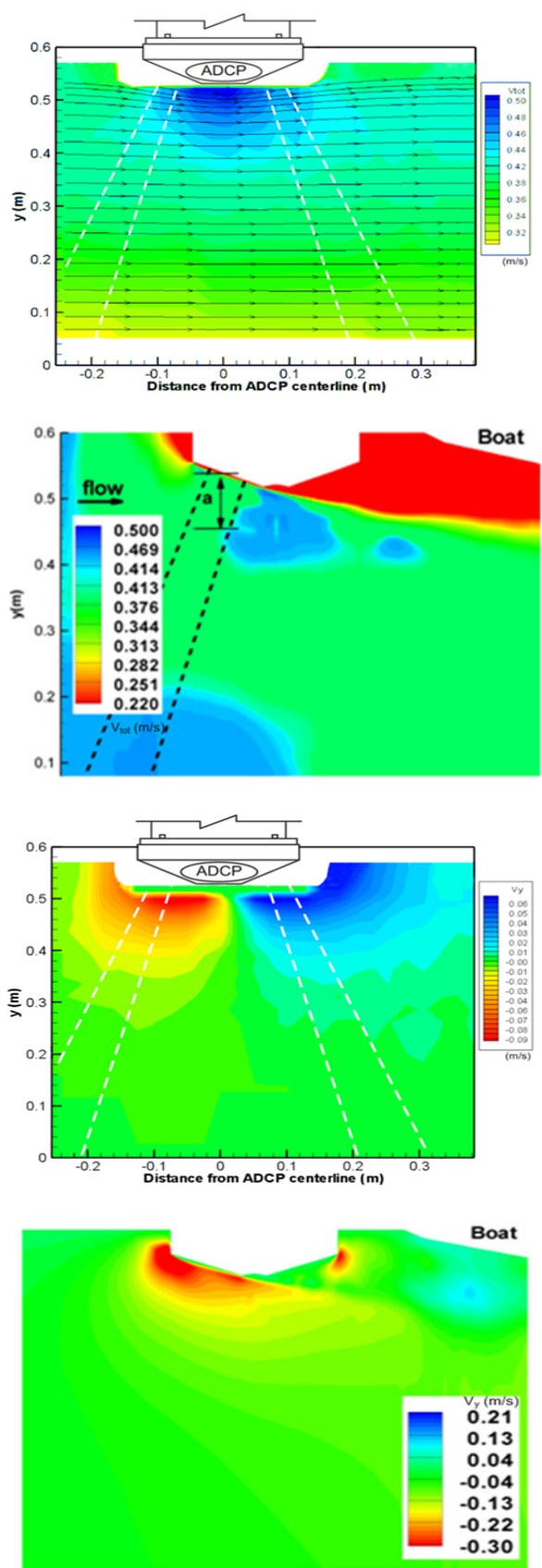

[Fig. 3] Comparison of mean flow predictions in the vertical plane oriented in the mean flow direction cutting through the axis of the ADCP. a) streamwise velocity experiment; b) streamwise velocity, LES; c) vertical velocity, experiment; d) vertical velocity, LES. Distance A indicates the vertical length where the total flow velocity vector is perpendicular to the Beam 3 direction $\pm 2^{\circ}$ tolerance interval.
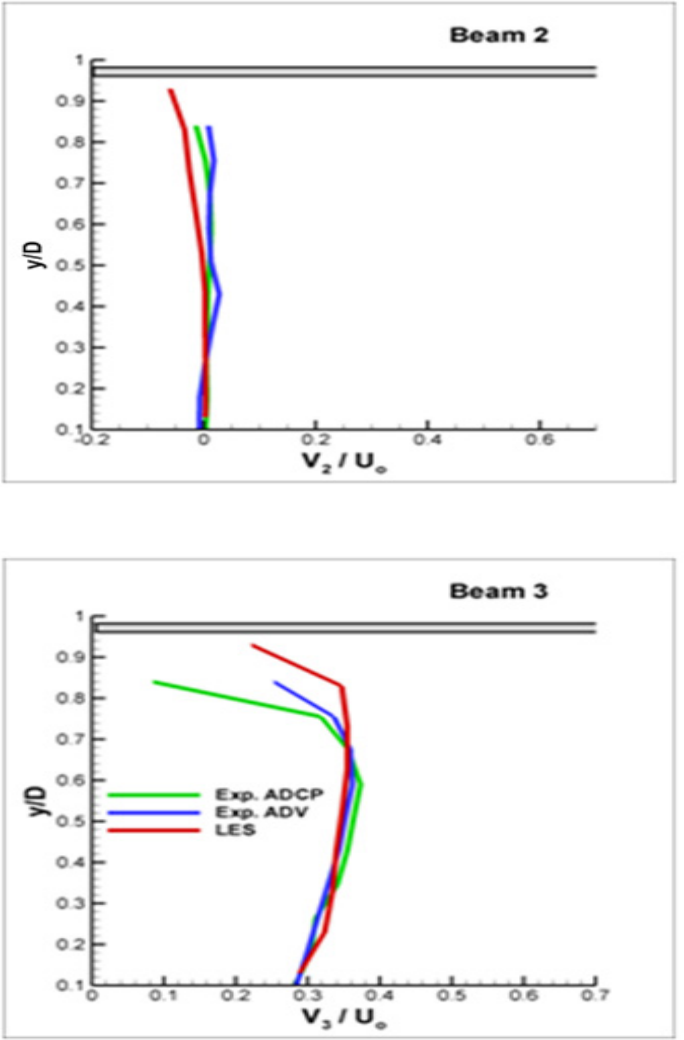

[Fig. 4] Radial along-the-beam velocities measured along beam 3 (left frame and along beam 2 (right frame). Beam 3 points upstream and away from the boat while beam 2 points laterally (see Figure 1).Shaded area in the figure represents the region (a) in Figure 3.

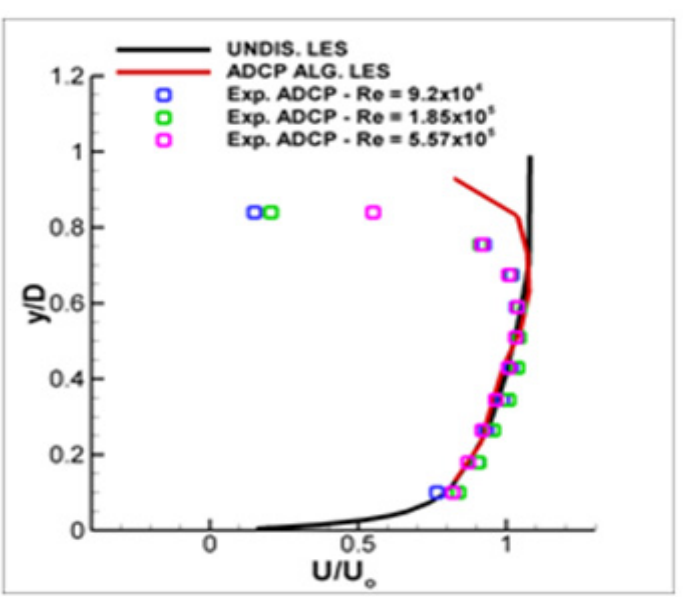




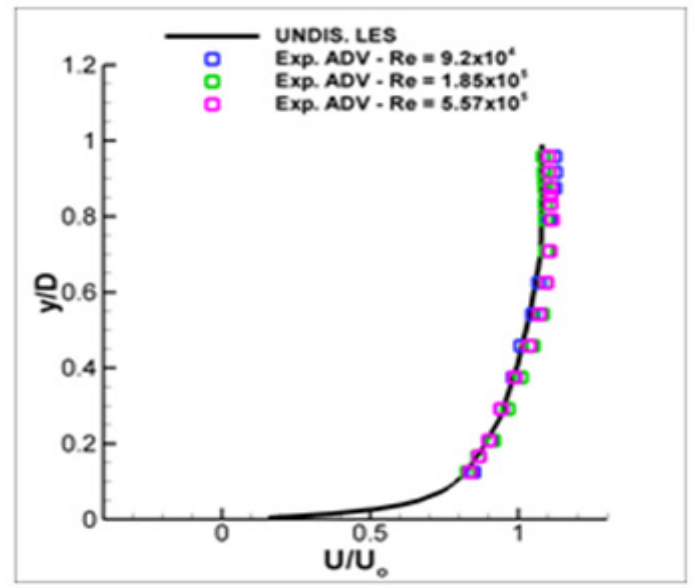

[Fig. 5] Comparison of vertical profiles of the streamwise velocity a) streamwise velocity profiles measured by $\mathrm{ADV}$ and predicted by LES for undisturbed flow (no ADCP present); b) streamwise velocity profiles measured by ADCP and predicted by LES simulation containing ADCP and boat showing there is a low bias close to the ADCP. The LES predicted profile for channel flow with no disturbance due to instrument is shown with the solid black line. The red line corresponds to the profile of the streamwise velocity calculated using the ADCP algorithm from time series collected along the ADCP beams using data from the ADCP and boat disturbed LES solution. The right frame contains ADCP measured profiles of the streamwise velocity from three experiments conducted with different Reynolds numbers.

\section{Acknowledgement}

The authors appreciate through aids from Talya Tokyay, Marian Muste, and George Constantinescu to finish the paper.

\section{References}

[1] Abad, J. Musalem, R., García, M., Cantero, M and García, M.H., 2004. Exploratory study of the influence of the wake produced by Acoustic Doppler Velocimeter probes on the water velocities within measurement volume. Proceedings of the ASCE/EWRI World Water and Environmental Resources Congress, Salt Lake City, Utah, USA.

[2] Gartner, J.W. and N. Ganju, N., 2002. A preliminary evaluation of near transducer velocities collected with low-blank ADCP. Proceedings of the ASCE-IAHR Hydraulic Measurements and Experimental Methods Conference, ASCE, Reston, Va.

[3] Mahesh, K., Constantinescu, S.G. and Moin, P., 2004. A numerical method for large eddy simulation in complex geometries. Journal of Computational Physics, Vol. 197, 215-240

[4] Mueller, D.S., Abad, J.D., García, C.M., Gartner, J.W., García, M.H., and Oberg, K.A., 2007. Errors in acoustic Doppler profiler velocity measurements caused by flow disturbance. Journal of Hydraulic Engineering, ASCE, Vol. 133(12), 1411-1420.

[5] Muste, M., Kim, D., Gonzalez-Castro, J., Burkhardt, A., and Brownson, Z., 2006. Near-transducer errors in ADCP measurements. Proceedings of the ASCE-EWRI World Environmental and Water Resources Congress, (CD-ROM), Omaha, Nebraska

[6] Tokyay T., Constantinescu, S.G. and Gonzales-Castro, J., 2008. An LES investigation of two elemental error sources in boat-mounted ADCP measurements. International conference on fluvial hydraulics, River Flow 2008, Izmir, Turkey, September 2008.

\section{김 동 수(Kim Dong-Su)}

[정회원]

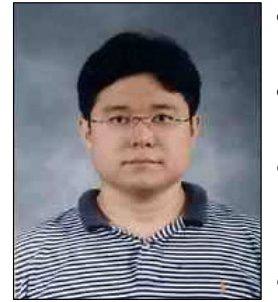

- 1998년 2월 : 서울대학교 공과대 학 토목공학과 (공학사)

- 2000년 2월 : 서울대학교 대학원 토목공학과 (공학석사)

- 2008년 8월 : 미국 University of Iowa, Dept. of Civil Engineering (공학박사)

- 2010년 9월 현재 : 단국대학 교 토목환경공학과 교수

<관심분야>

$\mathrm{ADCP}$ 유량계측, 수리정보화시스템, GIS 기반의 해석기 법 개발 
강 부 식(Kang Boo-Sik)

[정회원]

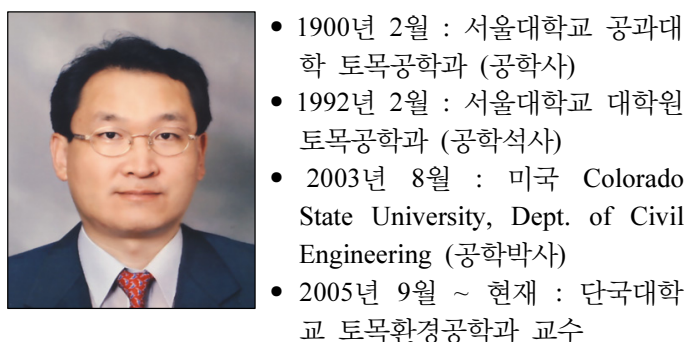

<관심분야>

기후변화, 강우-유출모형, 수자원관리 